\title{
ANTI-ULCER STUDY OF STANDARDIZED ETHANOL ROOT EXTRACT OF AGANOSMA DICHOTOMA AND ISOLATED URSOLIC ACID
}

\author{
DEEPALI PANDEY, APURVA JOSHI, SIVA HEMALATHA*
}

Department of Pharmaceutics, Indian Institute of Technology (Banaras Hindu University), Varanasi 221005, India

Email: shemalatha.phe@itbhu.ac.in

Received: 06 Jan 2017 Revised and Accepted: 27 Feb 2017

\section{ABSTRACT}

Objective: Aganosma dichotoma K. Schum (Apocynaceae) has been traditionally used as an Ayurvedic ulcer treatment and the study scientifically validates the antiulcer effect of $A$. dichotoma ethanol root extract (EAD).

Methods: The studies included the isolation, quantification of ursolic acid through HPTLC. Acute and sub-acute toxicity study of EAD for $28 \mathrm{~d}$ and antiulcer effect of ursolic acid (50 mg/kg, p. o.), EAD (100, 200 and $400 \mathrm{mg} / \mathrm{kg}$, p. o.) were also evaluated on both the physical (pyloric ligation, PL; cold restrain stress, CRS;) and chemical (absolute ethanol, aspirin, ASP;) induced ulcer in Charles Foster albino rats for 7 d. The various gastric-ulcer parameters, viz. gastric $\mathrm{pH}$, volume, acid-pepsin output, DNA content, $\mathrm{H}^{+} \mathrm{K}^{+}$-ATPase activity, mucus content, microvascular permeability, antioxidant enzyme, and gastric histopathological study were performed.

Results: The isolated ursolic acid was characterized by NMR and mass spectrometer and quantified through HPTLC in EAD (4.26\% w/w). Acute oral toxicity study indicated that $\mathrm{LD}_{50}$ of extract was $\geq 5 \mathrm{~g} / \mathrm{kg}$. EAD at the dose of 200 and $400 \mathrm{mg} / \mathrm{kg}$, p. o. reduced the ulcer score in both physical and chemical-induced ulcer models. In PL model EAD (400 mg/kg, p. o.) and ursolic acid (50 mg/kg, p. o.) showed antisecretory property by inhibiting aggressive factors [increase in gastric pH (35.02\%, 26.73\%), whereas decreased gastric volume (43.55\%, 34.35\%) and acid-pepsin output (75.23\%, $68.81 \%$ ), respectively]. EAD at $400 \mathrm{mg} / \mathrm{kg} \mathrm{p}$. o. showed significant effect on proton pump inhibition while ursolic acid didn't showed any effect.

Conclusion: The effects of EAD were accredited mainly to the offensive mechanism and justify its traditional usage in the treatment of gastric ulcers.

\section{Keywords: HPTLC, Gastric ulcer, Antisecretory, $\mathrm{H}^{+} \mathrm{K}^{+}$-ATPase inhibitor}

(C) 2017 The Authors. Published by Innovare Academic Sciences Pvt Ltd. This is an open access article under the CC BY license (http://creativecommons.org/licenses/by/4.0/) DOI: http://dx.doi.org/10.22159/ijpps.2017v9i4.16957

\section{INTRODUCTION}

Gastric ulcer is a widespread global problem in the modern era; it is estimated that around 14.5 million of the worldwide population is affected, with a mortality of 4.08 million [1]. The pervasiveness of gastric ulcer is due to behavioral and environmental factors such as inadequate dietary habits, smoking, excessive use of non-steroidal anti-inflammatory agents (NSAIDs), stress, hereditary predisposition, and infection with Helicobacter pylori [2,3]. Out of the above mentioned factors infection with $H$. pylori and long-term use of NSAIDs, are the most prevalent for the development of gastric ulcer [4]. Inhibition of gastric acid secretion by histamine receptor blockers, proton pumps inhibitors or enhancing the mucosal production (prostaglandin analogues or certain antimicrobials) are common strategies in modern ulcer treatment [5]. These available antiulcer drugs are associated with adverse complications including, hypersensitivity, arrhythmia, impotence, gynecomastia, and hematopoietic disorder [6, 7]. Currently, ethno-medicinal plants contribute to the drug development process and are a major focus in global health care. Plant extracts are important sources of new drug development and have been shown to produce potent results for the treatment of gastric ulcer $[8,9]$.

About 80 species of plants of the Apocynaceae family show medicinal importance and are often used to treat gastrointestinal ailments, reduce fever and pain, treat diabetes and infectious disease, etc. [10]. Aganosma dichotoma K. Schum (Apocynaceae) is commonly known as Malati in Hindi and Jati in Sanskrit. Eight species of Aganosma are found and distributed in India, China, Philippines, and Indonesia. In India, it mainly extends throughout Assam, Bihar, West Bengal, Orissa, Andhra Pradesh, and Tamil Nadu. Blume was first to describe Aganosma genus under class of Echites which attained the generic status by G. Don (1837) with other species based on specimens in Wallich's herbarium [11, 12]. A. dichotoma is traditionally used as anemetic, anthelmintic, in bronchitis, leprosy, skin diseases, ulcer, inflammations, arthritis, purulent discharges from the ear, and diseases of the mouth. Flowers are useful in eye diseases and leaves cure biliousness [13, 14]. Thus, the present investigation was aimed to establish the scientific validation of $A$. dichotoma in treatment of gastric ulcer.

\section{MATERIALS AND METHODS}

Materials

Chemicals

Tris buffer, Evans blue dye, Alcian blue dye, Topfers reagent and Folin-ciocalteu reagent were purchased from Sigma Aldrich (Germany). Some markers of analytical standards like Ursolic acid, Tannic acid, Rutin and Diosgenin were also purchased from Sigma Aldrich (Germany). Standard drug Omeprazole was obtained from Cadilla Pharmaceuticals Ltd. (India). All other chemicals and solvents used were of analytical grade.

\section{Plant material}

The roots of $A$. dichotoma were collected in the month of April 2013 from Tumbura Kona Kshetram at Seshachalam hills and Tirumala hills, Chittor District (13.2218 $\left.{ }^{\circ} \mathrm{N}, 79.1010^{\circ} \mathrm{E}\right)$, Andhra Pradesh, South India and authenticated by Dr. K. Madhava Chetty, Taxonomist, S. V. University, Tirupati. A voucher specimen (COG/AD/17) has been kept in Department of Pharmaceutics, IIT$\mathrm{BHU}$, Varanasi, India for further reference.

\section{Animals}

Adult Charles Foster albino rats $(150 \pm 10 \mathrm{~g})$ of either sex were obtained from the Central Animal House, Institute of Medical Sciences, Banaras Hindu University and were used for the study. The pharmacological experiments were performed after the approval obtained from the Central Animal Ethical Committee, Institute of 
Medical Sciences, Banaras Hindu University (Approval no.: Dean/ 2015/CAEC/983). The rats were housed in stainless steel wire mesh cages up to a maximum of 6 per cage, in a well-ventilated room with $12 \mathrm{~h} \mathrm{light/dark} \mathrm{cycle} \mathrm{and} \mathrm{fed} \mathrm{with} \mathrm{commercial} \mathrm{rat} \mathrm{feed} \mathrm{and} \mathrm{water} a d$ libitum. The animals were fasted for $18 \mathrm{~h}$ with free access to water prior to the experiment.

\section{Methods}

\section{Preparation of plant extract}

The roots were shade dried and grounded into a coarse powder which was subjected to Soxhlet extraction with $95 \%$ ethanol $11 \mathrm{~kg}$ powdered drug in $3 \mathrm{l}$ ethanol) up to $72 \mathrm{~h}$ at $45^{\circ} \mathrm{C}$. The root extract of A. dichotoma (EAD) thus obtained was dried and concentrated in a rotary evaporator (IKA Germany).

\section{Phytochemical evaluation}

The preliminary phytochemical screening was done on EAD to determine the presence of different phytoconstituents by using standard procedures [15]. Thereafter, spectrophotometric quantification of phytoconstituents present in EAD was evaluated for the total content of phenolics and tannins [16], flavonoids and flavonols [17], saponins [18].

\section{Isolation and quantification of ursolic acid}

The dried EAD was made hydro-alcoholic (7:3) and then subjected to successive fractionation using solvents of increasing polarity such as petroleum ether, chloroform, ethyl acetate and butanol. Based on maximum \% yield, petroleum ether fraction $(9 \mathrm{~g})$ was subjected to column chromatography on silica gel. It was eluted with chloroformmethanol (8:2), total 16 fractions were collected and pooled. All the pooled fractions were concentrated under vacuum evaporator to minimum volume and were kept undisturbed for two days which later yielded the compound PEF-1. The compound was recrystallized in methanol and subjected to characterization by NMR and mass spectrometry. EAD was standardized with quantification of ursolic acid by using high-performance thin-layer chromatography (HPTLC)[19]. A stock solution of EAD $(10 \mathrm{mg} / \mathrm{ml})$, and ursolic acid (Sigma) $(1 \mathrm{mg} / \mathrm{ml})$ was prepared in methanol. Toluene: Ethyl acetate: a Formic acid mixture in the ratio of 7:3:0.1 (v/v/v) was used as a mobile phase for developing the chromatogram. Camag-HPTLC instrumentation (Camag, Mutten, Switzerland) equipped with Linomat V sample applicator, Camag TLC scanner 3, Camag TLC visualizer and WINCATS 4 software for data interpretation was used for the study.

\section{Acute oral toxicity study}

Acute oral toxicity study of EAD was performed on 24 animals (equally divided into four groups). The extract was administered as $0.5 \%$ carboxymethylcellulose (CMC), and Tween 80 , suspension at doses of $1,2.5$ and $5 \mathrm{~g} / \mathrm{kg}$ body weight and the control group received the $0.5 \%$ CMC suspension only. Rats were deprived of food and water up to $4 \mathrm{~h}$ after drug treatment. Animals were closely observed for the initial $4 \mathrm{~h}$ after the administrations, and then once daily up to $14 \mathrm{~d}$. The survival rate of rats was recorded at the end [20].

\section{Subacute oral toxicity study}

Adult Charles Foster albino rats $(150 \pm 10 \mathrm{~g})$ of either sex were distributed into 4 groups (A1, A2, A3 and control) of 10 animals each and OECD guideline 407 was followed. EAD was administered orally for 28 consecutive days in the doses of 250,500 , and $1000 \mathrm{mg} / \mathrm{kg}$ (A1, A2 and A3). Body weight of animals, food and water consumption were monitored daily throughout the study period. On $29^{\text {th }}$ day blood was collected from overnight fasted rats by retroorbital plexus under light anesthesia. The collected blood samples were analyzed for haematological and biochemical parameters. After that, animals were sacrificed and examined for the histopathological changes of liver and kidney [21].

\section{Gastric ulcer studies in pylorus ligation induced model (PL)}

The animals were divided into seven groups of six animals each $(\mathrm{n}=$ 6 ). Group 1 controlled received distilled water as the vehicle, group 2 was gastric ulcer control received $0.5 \%$ CMC suspended in distilled water, group 3 was standard drug treated received omeprazole 20 $\mathrm{mg} / \mathrm{kg}$, p. o., (Cadila Pharmaceuticals Ltd.), group 4-6 was EAD treated received 100, 200 and $400 \mathrm{mg} / \mathrm{kg}$, p. o., and group 7 was ursolic acid $(50 \mathrm{mg} / \mathrm{kg}, \mathrm{p}$. o.) treated. All the standard and tested drugs were suspended in $0.5 \%$ CMC and 2 drops of Tween 80 and administered orally for a period of seven days. On the seventh day of study, pylorus ligation on the rat stomach was done under the anesthetized condition, according to the method of Shay et al. (1945) [22]. The abdomen was cut, then opened and the pyloric end was subjected to the ligation without damaging effect to the blood supply. The stomach was cautiously replaced and with the help of interrupted sutures the abdomen was closed. After this postoperative period, the rats were destitute of water up to $4 \mathrm{~h}$ after that animal were sacrificed by euthanasia and stomach was dissected out from greater curvature for ulcer scoring [23]. The ulcer index was calculated according to the method of Sanyal et al. (1983) by adding the total number of ulcers per stomach and the total severity of ulcers per stomach [24]. The total severity of the ulcers was estimated after histological confirmation as shown below:

[0]: no ulcer.

[+]: pinpoint ulcer and histological changes limited to superficial layers of mucosa and no congestion.

[++]: ulcer size less than $1 \mathrm{~mm}$ and half of the mucosal thickness showed necrotic changes.

[+++]: ulcer size 1-2 $\mathrm{mm}$ with more than two-thirds of the mucosal thickness destroyed with marked necrosis and congestion, muscle is remaining unaffected.

[++++]: ulcer either more than $2 \mathrm{~mm}$ in size or perforated with the complete destruction of the mucosa with necrosis and hemorrhage, muscle is still remaining unaffected.

The $\%$ protection was calculated by using the following formulae.

$\%$ protection $=[$ Ulcer index $($ Control) - Ulcer index $($ Treated $)] /$ Ulcer index (Control) X 100

\section{Determination of gastric secretion study in PL}

The stomach of all the groups was removed, inspected internally, and its contents were drained into a graduated centrifuge tube (centrifuged at $3000 \mathrm{rpm}$ for $10 \mathrm{~min}$ at $25^{\circ} \mathrm{C}$ ) and gastric secretion study was evaluated from $4 \mathrm{~h}$ PL rats. Parameters such as gastric juice volume (mL/100 $g$ body weight), $\mathrm{pH}$ (using $\mathrm{pH}$ meter), total gastric secretion acid content were determined by titrating with $0.1 \mathrm{~N} \mathrm{NaOH}$ using Topfer's reagent and phenolphthalein as indicators (expressed as $\mathrm{mEq} / 4 \mathrm{~h}$ acid output) and total pepsin output with hemoglobin as substrate (expressed as mmol tyrosine/4 h) [25]. 90\% alcohol was added to precipitate dissolved mucosubstances in the gastric juice, and total carbohydrate and protein content were determined [26]. The ratio of total carbohydrate to protein (TC: P) was taken as an indicator of mucin activity. The result of total DNA content in the gastric juice (cell shedding) was expressed as $\mu \mathrm{g} / \mathrm{ml}$ gastric juice.

\section{Estimation of mucosal glycoprotein and DNA content in PL}

Samples of gastric mucosal scraping were homogenized in distilled water, and glycoprotein estimation was carried out in gastric mucosa from the $4 \mathrm{~h}$ PL rat stomach. The results were expressed as $\mu \mathrm{g} / 100 \mathrm{mg}$ wet tissue and TC: $\mathrm{P}$ ratio has been taken as the index of glycoprotein activity. Mucosal scrap was homogenized with $2.5 \mathrm{ml}$ ice cooled $0.6 \mathrm{~N}$ perchloric acid, and DNA content was determined. DNA cell proliferation result was articulated as $\mu \mathrm{g}$ DNA/100 mg tissue [27].

\section{Determination of inhibition of $\mathrm{H}^{+} \mathrm{K}^{+}$-ATPase enzymatic activity in PL}

$\mathrm{H}^{+} \mathrm{K}^{+}-\mathrm{ATPase}$ inhibitory activity was assessed by using the method described by Reyes-Chilpa et al. (2006). $\mathrm{H}^{+} \mathrm{K}^{+}-\mathrm{ATPase}$ enzymatic inhibition was evaluated on gastric microsomes from $4 \mathrm{~h}$ PL rats [28]. The mucosa was scraped from gastric fundus region and suspended in EGTA-sucrose buffer solution (250 mmol sucrose, $2 \mathrm{mmol} \mathrm{MgCl}_{2}, 1$ mmol EGTA and 2 mmol Tris buffer, maintained at pH 7.4) followed by $3 \mathrm{~min}$ homogenization. Preparation of gastric microsomes was 
processed by successive centrifugation at $3000 \mathrm{rpm}$ for $10 \mathrm{~min}$ and $20,000 \mathrm{rpm}$ for $30 \mathrm{~min}$ at $4{ }^{\circ} \mathrm{C}$ two times, from which the nuclei, mitochondria and microsomes were obtained. The supernatant of the resulting solution was discarded and the microsome pellet was obtained, which was dissolved and homogenized in mannitol buffer solution $(250 \mathrm{mmol}$ mannitol, $2 \mathrm{mmol}$ magnesium chloride and 2 mmol Tris buffer maintained at $\mathrm{pH}$ 7.4). The obtained homogenate $(0.1 \mathrm{ml})$ was further processed by adding $0.2 \mathrm{ml}$ Tris buffer-HCl $(20$ mmol, pH 7.4), $0.2 \mathrm{ml} 2 \mathrm{mmol} \mathrm{MgCl}_{2}$ and $0.2 \mathrm{ml} 2 \mathrm{mmol} \mathrm{KCl}$. After that $0.2 \mathrm{ml} 2 \mathrm{mmol}$ ATP was added to start the reaction and incubated at $37{ }^{\circ} \mathrm{C}$ for $30 \mathrm{~min}$ and later ended by adding $10 \%$ trichloroacetic acid followed by centrifugation at $2000 \mathrm{rpm}$ for $10 \mathrm{~min}$. The inorganic phosphate (Pi) generated was evaluated by Shimadzu spectrophotometer (UV-1700, Singapore) at $640 \mathrm{~nm}$ and result was expressed in terms of $\mu \mathrm{M}$ Pi liberated/mg protein/min [29].

\section{Cold restrain stress induced ulcer (CRS)}

The animals were subjected to cold restrain stress after $1 \mathrm{~h}$ treatment with EAD at doses of 100,200 , and $400 \mathrm{mg} / \mathrm{kg}$, p. o., ursolic acid ( $50 \mathrm{mg} / \mathrm{kg}$, p. o.) and omeprazole $(20 \mathrm{mg} / \mathrm{kg}$, p. o.). The fore and hind limbs were tied up on a wooden slab of overnight fasted rats and kept at a temperature of $4-6^{\circ} \mathrm{C}$ for $2 \mathrm{~h}$ to induce cold restrain stress [30]. Thereafter, the animals were sacrificed by euthanasia $3 \mathrm{~h}$ after CRS and ulcers were evaluated on the dissected stomach. Ulcer index was scored as per methods described under the PL-induced ulcer model [31].

\section{Ethanol-induced ulcer}

To induce ulcer with ethanol, animals were fasted for $24 \mathrm{~h}$ and rats were given ursolic acid $(50 \mathrm{mg} / \mathrm{kg}, \mathrm{p} . \mathrm{o}), \mathrm{EAD}$ at the doses of 100 , 200 and $400 \mathrm{mg} / \mathrm{kg}$; p. o., positive control received omeprazole at the dose of $20 \mathrm{mg} / \mathrm{kg}, \mathrm{p}$. o., while the negative control received distilled water. After $1.5 \mathrm{~h}$, absolute ethanol (95-99\%), (1 ml/200 g, p. o.) was administered. After $1 \mathrm{~h}$ administration of ethanol, animals were sacrificed by euthanasia, and the stomach was incised along the greater curvature for scoring of ulcer [32].

\section{Determination of mucosal microvascular permeability in ethanol-induced ulcer}

The microvascular permeability test was performed on $1 \mathrm{~h}$ absolute ethanol rats by using Evans blue dye (EBD), which was shown as an indicator of increased capillary permeability. EBD $(10 \mathrm{mg} / \mathrm{kg}$, i. v. $)$ was administered 30 min prior to animal sacrifice. The mucosal tissue was scraped from the stomach and soaked in $1 \mathrm{ml} 1 \mathrm{~N} \mathrm{KOH}$ at $37{ }^{\circ} \mathrm{C}$ overnight. $9 \mathrm{ml}$ of a mixed solution of $0.6 \mathrm{~N}$ phosphoric acid and acetone (5:13) was prepared and added to the tube, followed by vigorous shaking for a few seconds after which was centrifuged at $3000 \mathrm{rpm}$ for $15 \mathrm{~min}$. The absorbance of the supernatant was measured at $620 \mathrm{~nm}$ and the results were indicated as $\mu \mathrm{g}$ Evans blue $/ g$ of tissue [33].

\section{Estimation of mucus content in the gastric wall in ethanol- induced ulcer}

According to Corne et al. (1974), gastric mucus content was determined from the $1 \mathrm{~h}$ absolute ethanol rats by reacting with alcian blue dye [34]. The concentration of the dye was estimated by using spectrophotometer at $580 \mathrm{~nm}$ from the alcian blue standard calibration curve. The mucus content was expressed in terms of $\mu \mathrm{g}$ alcian blue $/ g$ wet tissue.

\section{Antioxidant activity and free radical determination in ethanol- induced ulcer}

Antioxidant enzymes like superoxide dismutase (SOD), catalase (CAT), glutathione (GSH) and lipid peroxides (LPO) were determined on mucosal tissue scrap accessed from the $1 \mathrm{~h}$ ethanol rat stomach. Followed by homogenization of mucosal scrap was done in $0.9 \%$ ice cold saline for 30 seconds. Successive centrifugation was done initially at $800 \mathrm{xg}$ for $10 \mathrm{~min}$ and later at $12,000 \mathrm{xg}$ for $15 \mathrm{~min}$. The clear supernatant was used for the above estimations [35-39].

\section{Histopathological studies in ethanol-induced ulcer}

Stomach sample from $1 \mathrm{~h}$ absolute ethanol-induced ulcerated rats of all the groups was fixed using $10 \%$ formalin. The tissue was then embedded in paraffin blocks for preparing sections (1-3 $\mu \mathrm{m})$ which were then stained using hematoxylin and eosin dye and photographed by using a Nikon digital microscope (Eclipse 200) at 10x magnifications.

\section{Aspirin-induced ulcer (ASP)}

Pretreatment of animals were done with EAD at dose of 100, 200, and $400 \mathrm{mg} / \mathrm{kg}$, p. o. ursolic acid $(50 \mathrm{mg} / \mathrm{kg}$, p. o.) and with omeprazole $20 \mathrm{mg} / \mathrm{kg}$, p. o. for $7 \mathrm{~d}$. On $7^{\text {th }}$ day of the experiment, ASP was administered to the overnight fasted rats at the dose of 200 $\mathrm{mg} / \mathrm{kg}, \mathrm{p}$. o. The animals were sacrificed by euthanasia $4 \mathrm{~h}$ later of ASP administration and the ulcers were scored [6].

\section{Statistical analysis}

Results are expressed as mean \pm SEM with $n=6$ per group. Statistical significance was determined using one-way analysis of variance (ANOVA) followed by Tukey's posttest for multiple group comparison. The difference was considered to be significant when $\mathrm{p}<0.05$.

\section{RESULTS}

\section{Phytochemical evaluation}

The qualitative phytochemical screening of EAD showed the presence of phenolics, tannins, flavonoids, steroids, saponin, carbohydrate, steroid, and anthraquinone glycosides. Quantification of total phenolic and tannin content in EAD was found to be $125.65 \pm 2.58$ and $104.96 \pm 1.35 \mathrm{mg} / \mathrm{g}$ (tannic acid equivalent per gram plant material), respectively. Total flavonoids and flavonols content were found to be $62.20 \pm 2.01$ and $1.97 \pm 0.06 \mathrm{mg} / \mathrm{g}$ (rutin equivalent per gram plant material), respectively. Whereas total saponin content was found to be $49.2 \pm 1.92 \mathrm{mg} / g$ (diosgenin equivalent per gram plant material).

\section{Characterization and quantification of ursolic acid}

The characteristics signals (chemical-shifts) in ${ }^{1} \mathrm{H}-\mathrm{NMR}$ and ${ }^{13} \mathrm{C}-\mathrm{NMR}$ spectra's of the investigated compound (PEF-1) was recorded in $\mathrm{CDCl}_{3}$. In ${ }^{1} \mathrm{H}-\mathrm{NMR}$ spectral data, the characteristic sharp singlet peak of the acidic proton was observed at $9.85 \mathrm{ppm}$ (downfield chemical shift), whereas the $(-\mathrm{OH})$ proton was observed as doublet at 1.634 $\mathrm{ppm}$, This $\mathrm{OH}$ proton was further confirmed in $\mathrm{D}_{2} \mathrm{O}$ shake spectrum(this peak is missing). In ${ }^{13} \mathrm{C}$-NMR spectrum, the characteristic peaks of $\mathrm{COOH}$ carbon was found at $182.70 \mathrm{ppm}$ while carbon atoms attached with double bond were found at 148.18, 120.47 ppm, respectively. Carbon atom attached with OH group was found at $76.73 \mathrm{ppm}$. In mass spectrum, ESI-MS methanol the characteristic $\mathrm{M}^{+}$was observed at $\mathrm{m} / \mathrm{z} 456.7$ (9.7\%), whereas the $\mathrm{M}$ $18,439.2(53.3 \%)$ and 438.2 (5.5\%) M-19 peaks were also observed in the spectrum.

The base peak was observed at $411.2(100 \%)$. On the bases of spectral observations, it was found that PEF-1 is ursolic acid. Quantification of ursolic acid was analyzed in EAD by HPTLC as shown in fig. 1 and the result shows that $4.26 \% \mathrm{w} / \mathrm{w}$ of ursolic acid was found in EAD and $\mathrm{R}_{\mathrm{f}}$ value 0.34 .

\section{Acute toxicity study}

Rats did not show any abnormal behaviour except for mild sedation after EAD administration for initial $4 \mathrm{~h}$. After $14 \mathrm{~d}$ of treatment with EAD, no mortality was observed.

\section{Sub-acute toxicity study}

The body weight of EAD treated rats was normal in comparison to vehicle treated rats. As summarized in Tables 1 and 2, EAD treatments did not significantly change the hematological and biochemical parameters. Histopathological examination of control and EAD treated rats exposed the absence of any gross pathological lesion in liver, kidney, heart and spleen. 

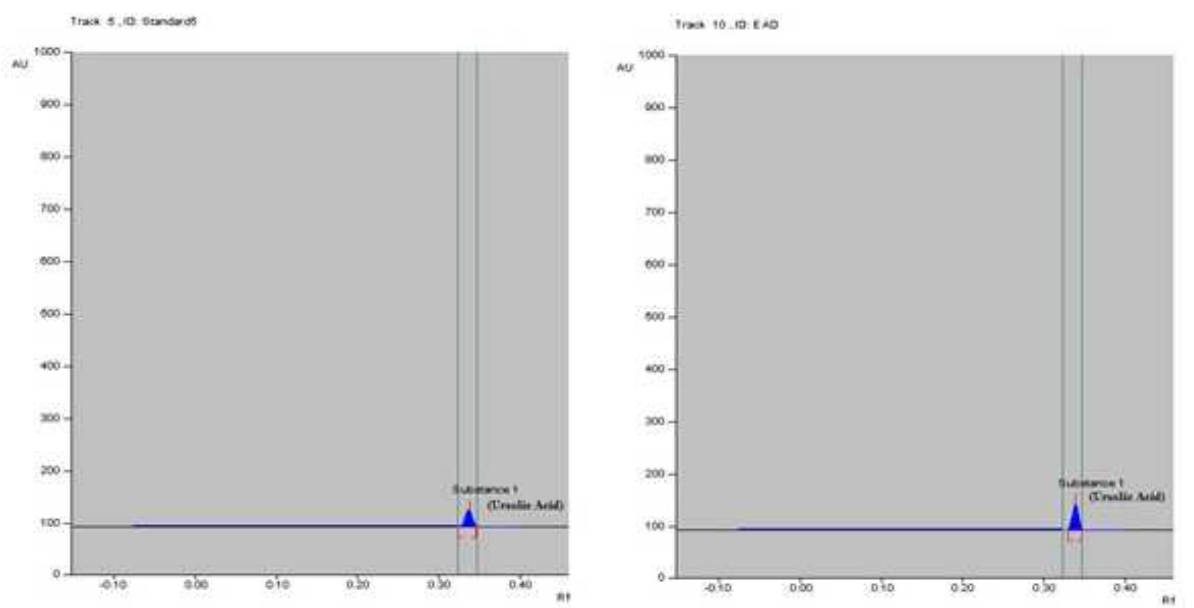

Fig. 1: HPTLC densitogram of standard ursolic acid and in root extract

Table 1: Hematological parameters of ethanolic root extract of $A$. dichotoma

\begin{tabular}{|c|c|c|c|c|}
\hline Parameter & Control & $250 \mathrm{mg} / \mathrm{kg}$ & $500 \mathrm{mg} / \mathrm{kg}$ & $1 \mathrm{~g} / \mathrm{kg}$ \\
\hline Hemoglobin & $11.21 \pm 0.08$ & $12.20 \pm 0.17$ & $11.56 \pm 0.20$ & $11.14 \pm 0.04$ \\
\hline Red Blood Cells & $7.23 \pm 0.11$ & $7.27 \pm 0.07$ & $6.30 \pm 0.17$ & $7.24 \pm 0.09$ \\
\hline White Blood cells & $10.28 \pm 0.07$ & $9.80 \pm 0.04$ & $11.04 \pm 0.04$ & $10.88 \pm 0.10$ \\
\hline Hematocrit & $41.88 \pm 0.09$ & $41.66 \pm 0.25$ & $43.05 \pm 0.26$ & $42.95 \pm 0.14$ \\
\hline Platelet count & $891.33 \pm 1.45$ & $868.31 \pm 1.76$ & $899.66 \pm 2.33$ & $882.12 \pm 2.89$ \\
\hline Total Leukocyte Count & $6.82 \pm 0.03$ & $6.68 \pm 0.07$ & $6.84 \pm 0.04$ & $6.82 \pm 0.03$ \\
\hline Neutrophil & $57.22 \pm 0.22$ & $57.97 \pm 0.09$ & $58.38 \pm 0.13$ & $57.96 \pm 0.19$ \\
\hline Lymphocyte & $45.08 \pm 0.09$ & $45.56 \pm 0.13$ & $43.91 \pm 0.34$ & $43.26 \pm 0.19$ \\
\hline Eiosinophil & $1.24 \pm 0.02$ & $1.19 \pm 0.02$ & $1.25 \pm 0.02$ & $1.13 \pm 0.03$ \\
\hline Monocyte & $3.02 \pm 0.02$ & $2.99 \pm 0.03$ & $2.96 \pm 0.02$ & $2.54 \pm 0.04$ \\
\hline Basophil & 0 & 0 & 0 & 0 \\
\hline Packed Cell Volume & $44.27 \pm 0.03$ & $44.17 \pm 0.07$ & $44.08 \pm 0.06$ & $41.98 \pm 0.01$ \\
\hline Mean Corpuscular Volume & $55.14 \pm 0.03$ & $54.62 \pm 0.06$ & $55.36 \pm 0.02$ & $54.93 \pm 0.04$ \\
\hline Mean Corpuscular Hemoglobin & $18.65 \pm 0.03$ & $18.86 \pm 0.05$ & $18.06 \pm 0.20$ & $18.21 \pm 0.08$ \\
\hline Mean Corpuscular Hemoglobin Concentration & $32.27 \pm 0.05$ & $32.72 \pm 0.11$ & $32.31 \pm 0.12$ & $32.23 \pm 0.11$ \\
\hline
\end{tabular}

All statistical data was expressed in mean \pm SEM $(n=10)$ and determined by one-way ANOVA followed by Tukey's multiple comparison test and no significant effect was observed.

Table 2: Biochemical parameters of extract of $A$. dichotoma

\begin{tabular}{llll}
\hline Parameter & Control & $\mathbf{2 5 0} \mathbf{~ m g} / \mathbf{k g}$ & $\mathbf{5 0 0} \mathbf{~ m g} / \mathbf{k g}$ \\
\hline Glucose & $86.18 \pm 0.08$ & $86.56 \pm 0.13$ & $85.76 \pm 0.20$ \\
Cholesterol & $109.83 \pm 0.03$ & $111.02 \pm 0.12$ & $110.02 \pm 0.16$ \\
Triglyceride & $90.48 \pm 0.03$ & $90.30 \pm 0.07$ & $90.81 \pm 0.07$ \\
HDL & $78.56 \pm 0.20$ & $78.55 \pm 0.25$ & $78.62 \pm 0.12$ \\
LDL & $27.31 \pm 0.10$ & $27.13 \pm 0.04$ & $27.33 \pm 0.09$ \\
Urea & $39.25 \pm 0.24$ & $39.29 \pm 0.09$ & $39.99 \pm 0.10$ \\
Creatinine & $0.85 \pm 0.02$ & $0.89 \pm 0.03$ & $0.93 \pm 0.01$ \\
Total Protein & $6.05 \pm 0.02$ & $6.11 \pm 0.05$ & $6.11 \pm 0.01$ \\
Albumin & $2.60 \pm 0.05$ & $2.63 \pm 0.04$ & $2.59 \pm 0.01$ \\
Globulin & $35.73 \pm 0.01$ & $35.84 \pm 0.02$ & $36.08 \pm 0.03$ \\
ALT & $62.47 \pm 0.02$ & $62.83 \pm 0.02$ & $63.08 \pm 0.02$ \\
AST & $246.22 \pm 0.57$ & $242.66 \pm 0.87$ & $242.36 \pm 0.07$ \\
\hline
\end{tabular}

All statistical data was expressed in mean \pm SEM $(n=10)$ and determined by one-way ANOVA followed by Tukey's multiple comparison test and no significant effect was observed, HDL: High-Density Lipoprotein; LDL: Low-Density Lipoprotein; ALT: Alanine transaminase; AST: Aspartate transaminase

\section{Gastric ulcer studies}

Effect of EAD at doses of 100, 200 and $400 \mathrm{mg} / \mathrm{kg}$, p. o., for $7 \mathrm{~d}$ showed a protective effect against ulcer in a dose dependent manner. EAD at higher doses (200 and $400 \mathrm{mg} / \mathrm{kg}$, p. o.) showed a significant effect in PL, ethanol, CRS and ASP induced gastric ulcer models, while ursolic acid protects the ulcer only in PL induced and ethanol induced gastric ulcer model. Standard drug omeprazole $(20$ $\mathrm{mg} / \mathrm{kg}$, p. o.) showed significant protection against all the tested gastric ulcer models. The percentage protection and score of ulcer index were determined (table 3).

\section{Gastric secretion study}

In $4 \mathrm{~h}$ PL rats, ursolic acid (50 mg/kg, p. o.) and EAD (200 and 400 $\mathrm{mg} / \mathrm{kg}$, p. o.) in a dose-dependent manner, decreased the gastric juice volume, increase the gastric $\mathrm{pH}$ when compared to ulcer control group. Acid-pepsin output was significantly reduced with omeprazole (20 mg/kg, p. o.), ursolic acid (50 mg/kg, p. o.) and EAD ( 200 and $400 \mathrm{mg} / \mathrm{kg}$, p. o.) groups; however, EAD at all doses, ursolic acid and omeprazole did not show any significant effect on DNA content of gastric mucosa, thus demonstrating the absence of effect on cell proliferation, while EAD (200 and $400 \mathrm{mg} / \mathrm{kg}$, p. o.), ursolic 
acid (50 mg/kg, p. o.) and omeprazole (20 mg/kg, p. o.) showed significant effect on cell shedding (table 4). Furthermore, EAD, ursolic acid and the standard drug did not produce any significant effect on mucin activity as compared to the ulcer control group (table 5).

Table 3: Effect of graded dose ethanolic extract of root of $A$. dichotoma (EAD) and ursolic acid on pylorus ligated (PL, 4h), absolute ethanol (1h), cold restrain stress (CRS, $2 \mathrm{~h}$ ) and aspirin (ASP, 4h) induced gastric ulcers in rats

\begin{tabular}{|c|c|c|c|c|c|c|c|c|}
\hline \multirow[t]{2}{*}{ Groups } & \multicolumn{8}{|c|}{ Ulcer index and percentage protection } \\
\hline & PL & $\begin{array}{l}\% \\
\text { protection }\end{array}$ & $\begin{array}{l}\text { Ethanol } \\
\text { mm }^{2} / \text { rat }\end{array}$ & $\begin{array}{l}\% \\
\text { protection }\end{array}$ & CRS & $\begin{array}{l}\% \\
\text { protection }\end{array}$ & ASP & $\begin{array}{l}\% \\
\text { protection }\end{array}$ \\
\hline $\begin{array}{l}\text { Ulcer control } \\
(0.5 \% \text { CMC })\end{array}$ & $24.16 \pm 1.05$ & - & $32.83 \pm 0.79$ & - & $17.50 \pm 0.56$ & - & $22.83 \pm 1.01$ & - \\
\hline $\begin{array}{l}\text { Omeprazole } \\
(20 \mathrm{mg} / \mathrm{kg})\end{array}$ & $6.33 \pm 0.88^{a}$ & 73.80 & $5.66 \pm 0.66^{\mathrm{a}}$ & 82.74 & $9.16 \pm 0.79^{a}$ & 47.66 & $6.83 \pm 0.70^{\mathrm{a}}$ & 70.08 \\
\hline $\begin{array}{l}\text { EAD } \\
(100 \mathrm{mg} / \mathrm{kg})\end{array}$ & $21.5 \pm 1.06^{\mathrm{b}}$ & 11.01 & $30.16 \pm 0.75^{b}$ & 8.12 & $14.00 \pm 1.06^{\mathrm{ab}}$ & 20.00 & $20.16 \pm 1.17^{b}$ & 11.70 \\
\hline $\begin{array}{l}\text { EAD } \\
(200 \mathrm{mg} / \mathrm{kg})\end{array}$ & $14.60 \pm 1.05^{\mathrm{abc}}$ & 39.32 & $15.33 \pm 0.88^{\mathrm{abc}}$ & 53.30 & $12.66 \pm 0.88^{\mathrm{ab}}$ & 27.60 & $14.30 \pm 0.76^{\mathrm{abc}}$ & 37.23 \\
\hline $\begin{array}{l}\text { EAD } \\
(400 \mathrm{mg} / \mathrm{kg})\end{array}$ & $7.50 \pm 0.76^{\text {acd }}$ & 68.96 & $7.33 \pm 0.49$ acd & 77.66 & $10.00 \pm 0.68^{\mathrm{ac}}$ & 42.86 & $10.00 \pm 0.85^{\mathrm{acd}}$ & 56.20 \\
\hline $\begin{array}{l}\text { Ursolic Acid } \\
\text { (50 mg/kg) }\end{array}$ & $18.61 \pm 0.71^{\text {abe }}$ & 22.97 & $22.75 \pm 0.67^{\text {abcde }}$ & 30.70 & $14.76 \pm 0.81^{\text {be }}$ & 19.31 & $18.92 \pm 0.54^{\text {abde }}$ & 15.41 \\
\hline
\end{tabular}

All statistical data was expressed in mean \pm SEM and determined by one-way ANOVA followed by Tukey's multiple comparison test., ap<0.05 statistically significant as compare to ulcer control, ${ }^{b} \mathrm{p}<0.05$ statistically significant as compare to omeprazole, ${ }^{\mathrm{c}} \mathrm{p}<0.05$ statistically significant as compare to EAD 100 , ${ }^{\mathrm{d}} \mathrm{p}<0.05$ statistically significant as compare to EAD 200, e $\mathrm{p}<0.05$ statistically significant as compare to EAD 400, CMC: Carboxy Methyl Cellulose

Table 4: Effect of extract and ursolic acid on gastric juice volume, pH, free, total acid output and DNA content of gastric juice (cell shedding) and stomach mucosa (cell proliferation) in $4 \mathrm{~h}$ pylorus ligated rats for $7 \mathrm{~d}$

\begin{tabular}{|c|c|c|c|c|c|c|c|c|c|}
\hline \multirow[t]{2}{*}{ Groups } & \multirow{2}{*}{$\begin{array}{l}\text { Gastric } \\
\text { juice } \\
\text { volume } \\
\text { (ml/100g) } \\
\end{array}$} & \multirow{2}{*}{$\begin{array}{l}\text { Gastri } \\
\text { c pH }\end{array}$} & \multicolumn{2}{|c|}{ Acidity $(\mu \mathrm{Eq} / \mathrm{ml})$} & \multirow{2}{*}{$\begin{array}{l}\text { Total } \\
\text { Acid } \\
\text { output } \\
(\mu \mathrm{Eq} / 4 \mathrm{~h})\end{array}$} & \multicolumn{2}{|l|}{ Pepsin } & \multirow{2}{*}{$\begin{array}{l}\text { Gastric juice } \\
\text { cell } \\
\text { shedding } \\
(\mu \mathrm{g} \text { DA } / \mathrm{ml})\end{array}$} & \multirow{2}{*}{$\begin{array}{l}\text { Mucosal cell } \\
\text { proliferation } \\
(\mu \mathrm{g} \text { DNA/100 } \mathrm{mg} \\
\text { wet tissue) }\end{array}$} \\
\hline & & & $\begin{array}{l}\text { Free } \\
\text { Acid }\end{array}$ & Total Acid & & $\begin{array}{l}\text { Conc. }(\mu \mathrm{mol} \\
\text { tyrosine } / \mathrm{ml})\end{array}$ & $\begin{array}{l}\text { Output }(\mu \mathrm{mol} \\
\text { tyrosine } / 4 \mathrm{~h})\end{array}$ & & \\
\hline $\begin{array}{l}\text { Ulcer } \\
\text { control }\end{array}$ & $1.63 \pm 0.04$ & $\begin{array}{l}3.74 \pm 0 \\
.11\end{array}$ & $\begin{array}{l}42.80 \pm \\
1.50\end{array}$ & $\begin{array}{l}112.20 \pm 4.5 \\
1\end{array}$ & $\begin{array}{l}279.56 \pm 1 \\
5.44\end{array}$ & $289.21 \pm 12.91$ & $721.34 \pm 41.10$ & $95.81 \pm 1.87$ & $134.30 \pm 6.76$ \\
\hline $\begin{array}{l}\text { Omepraz } \\
\text { ole } 20\end{array}$ & $0.89 \pm 0.05^{\mathrm{a}}$ & $\begin{array}{l}5.33 \pm 0 \\
.11^{\mathrm{a}}\end{array}$ & $\begin{array}{l}23.21 \pm \\
0.90^{\mathrm{a}}\end{array}$ & $\begin{array}{l}45.46 \pm 3.50 \\
\mathrm{a}\end{array}$ & $\begin{array}{l}59.32 \pm 6.1 \\
2^{\mathrm{a}}\end{array}$ & $163.18 \pm 9.30^{\mathrm{a}}$ & $\begin{array}{l}213.70 \pm 19.81 \\
\text { a }\end{array}$ & $41.40 \pm 1.01^{\mathrm{a}}$ & $141.97 \pm 7.02$ \\
\hline EAD 100 & $1.48 \pm 0.02^{b}$ & $\begin{array}{l}3.89 \pm 0 \\
.18^{\mathrm{b}}\end{array}$ & $\begin{array}{l}41.06 \pm \\
1.52^{\mathrm{b}}\end{array}$ & $\begin{array}{l}110.13 \pm 5.2 \\
6^{b}\end{array}$ & $\begin{array}{l}242.68 \pm 1 \\
0.09^{\mathrm{ab}}\end{array}$ & $285.02 \pm 7.00^{\mathrm{b}}$ & $\begin{array}{l}630.12 \pm 22.90 \\
b\end{array}$ & $92.31 \pm 2.20^{\mathrm{b}}$ & $139.96 \pm 3.83$ \\
\hline EAD 200 & $1.06 \pm 0.05^{a}$ & $\begin{array}{l}4.89 \pm 0 \\
.12^{\mathrm{ac}}\end{array}$ & $\begin{array}{l}28.26 \pm \\
0.73^{\mathrm{abc}}\end{array}$ & $\begin{array}{l}65.93 \pm 2.50 \\
\text { abc }\end{array}$ & $\begin{array}{l}106.75 \pm 6 . \\
03^{\mathrm{abc}}\end{array}$ & $\begin{array}{l}253.50 \pm 12.11 \\
b\end{array}$ & $\begin{array}{l}413.74 \pm 34.10 \\
\mathrm{abc}\end{array}$ & $76.15 \pm 2.32^{\mathrm{abc}}$ & $146.13 \pm 2.44$ \\
\hline EAD 400 & $\begin{array}{l}0.92 \pm 0.03^{a} \\
c\end{array}$ & $\begin{array}{l}5.05 \pm 0 \\
.21^{\mathrm{ac}}\end{array}$ & $\begin{array}{l}26.33 \pm \\
0.54 \text { ac }\end{array}$ & $\underset{\mathrm{abc}}{52.86 \pm 3.00}$ & $\begin{array}{l}69.27 \pm 2.8 \\
7 \text { acd }\end{array}$ & $\begin{array}{l}198.90 \pm 7.30^{\mathrm{a}} \\
\mathrm{cd}\end{array}$ & $\begin{array}{l}261.88 \pm 11.00 \\
\text { acd }\end{array}$ & $\begin{array}{l}49.31 \pm 1.36^{\mathrm{abc}} \\
\mathrm{d}\end{array}$ & $153.46 \pm 4.41$ \\
\hline $\begin{array}{l}\text { Ursolic } \\
\text { acid } 50\end{array}$ & $\begin{array}{l}1.07 \pm 0.04^{\mathrm{a}} \\
\text { c }\end{array}$ & $\begin{array}{l}4.78 \pm 0 \\
.23^{\mathrm{ac}}\end{array}$ & $\begin{array}{l}32.71 \pm \\
0.88^{\text {abce }}\end{array}$ & $\begin{array}{l}74.23 \pm 2.86 \\
\text { abce }\end{array}$ & $\begin{array}{l}87.23 \pm 4.2 \\
1^{\mathrm{ac}}\end{array}$ & $\underset{b c d}{211.06 \pm 6.14^{a}}$ & $\begin{array}{l}344.51 \pm 16.10 \\
\mathrm{abc}\end{array}$ & $e_{e}^{68.43 \pm 1.78^{a b c}}$ & $141.22 \pm 2.12$ \\
\hline
\end{tabular}

All statistical data was expressed in mean \pm SEM and determined by one-way ANOVA followed by Tukey's multiple comparison test, ap $<0.05$ statistically significant as compare to ulcer control, ${ }^{b} \mathrm{p}<0.05$ statistically significant as compare to omeprazole, ${ }^{c} \mathrm{p}<0.05$ statistically significant as compare to EAD100, dp $<0.05$ statistically significant as compare to EAD200, ${ }^{\mathrm{e}} \mathrm{p}<0.05$ statistically significant as compare to EAD 400

Table 5: Effect of extract and ursolic acid on content of gastric juice mucoprotein and mucosal scrap glycoprotein in $4 \mathrm{~h}$ PL rats

\begin{tabular}{lcc}
\hline Groups & Total carbohydrate $(\mathbf{T C})$ & Total protein (TP) \\
\hline Gastric juice mucoprotein estimation $(\boldsymbol{\mu g} / \mathbf{m l})$ & \\
Ulcer control & $422.09 \pm 24.60$ & $307.06 \pm 16.71$ \\
Omeprazole20 & $495.72 \pm 11.50^{\mathrm{a}}$ & $286.92 \pm 4.30$ \\
EAD 100 & $427.54 \pm 10.00^{\mathrm{b}}$ & $270.95 \pm 5.21$ \\
EAD 200 & $460.12 \pm 11.10$ & $266.09 \pm 7.10^{\mathrm{a}}$ \\
EAD 400 & $463.91 \pm 7.30^{\mathrm{a}}$ & $264.27 \pm 9.11^{\mathrm{a}}$ \\
Ursolic acid50 & $441.64 \pm 7.28^{\mathrm{b}}$ & $276.41 \pm 3.41$ \\
Mucosal scrap glycoprotein estimation $(\boldsymbol{\mu g} / \mathbf{1 0 0} \mathbf{~} \mathbf{m g}$ tissue) & $1.41 \pm 0.15$ \\
Ulcer control & $1512.36 \pm 18.70$ & $1043.99 \pm 27.20$ \\
Omeprazole20 & $1593.57 \pm 24.92$ & $990.51 \pm 26.00$ \\
EAD 100 & $1504.48 \pm 17.00$ & $1015.51 \pm 23.22$ \\
EAD 200 & $1562.97 \pm 23.12$ & $988.43 \pm 26.41$ \\
EAD 400 & $1590.24 \pm 29.00$ & $983.57 \pm 9.42$ \\
Ursolic acid50 & $1538.12 \pm 14.10$ & $996.48 \pm 18.21$ \\
\hline
\end{tabular}

All statistical data was expressed in mean \pm SEM and determined by one-way ANOVA followed by Tukey’s multiple comparison test, ap $<0.05$ statistically significant as compare to ulcer control, ${ }^{\mathrm{b}} \mathrm{p}<0.05$ statistically significant as compare to omeprazole 


\section{Effect of EAD and ursolic acid on $\mathbf{H}^{+} \mathrm{K}^{+}$-ATPase enzymatic activity}

The antisecretory effect of EAD (200 and $400 \mathrm{mg} / \mathrm{kg}$, p. o.) and omeprazole $\left(20 \mathrm{mg} / \mathrm{kg}\right.$, p. o.) was confirmed from $\mathrm{H}^{+} \mathrm{K}^{+}$-ATPase activity as observed in PL rat model, while ursolic acid did not show any significant action on $\mathrm{H}^{+} \mathrm{K}^{+}$-ATPase activity. The percentage inhibition in descending order was omeprazole (76.63\%), EAD 400 (58.47\%) and EAD 200 (16.44\%) (fig. 2).

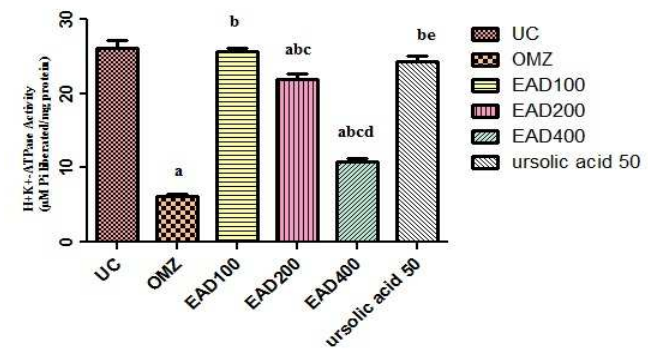

Fig. 2: Effect of EAD and ursolic acid on $\mathrm{H}^{+} \mathrm{K}^{+}$-ATPase enzymatic activity activity in $4 \mathrm{~h}$ PL rats

Statistical comparison was determined by one-way ANOVA followed by the Tukey's multiple comparison tests. (a) $\mathrm{P}<0.05$, statistically significant as compared to ulcer control. (b) $\mathrm{P}<0.05$, statistically significant as compared to omeprazole. (c) $\mathrm{P}<0.05$, statistically significant as compared to EAD 100. (d) $\mathrm{P}<0.05$, statistically significant as compared to EAD200. (e) $\mathrm{p}<0.05$ statistically significant as compare to EAD 400 .

\section{Effect of EAD on mucosal microvascular permeability}

EAD $400 \mathrm{mg} / \mathrm{kg}$, p. o., ursolic acid (50 mg/kg, p. o.) and omeprazole (20 mg/kg., p. o.) showed significant action on microvascular permeability in gastric mucosa induced by absolute ethanol as shown in fig. 3. The extrasavated amount of Evans blue dye in the gastric mucosa was decreased in these treated groups as compared to the ulcerated control group $(54.83,23.49$, and $59.35 \%)$, respectively.

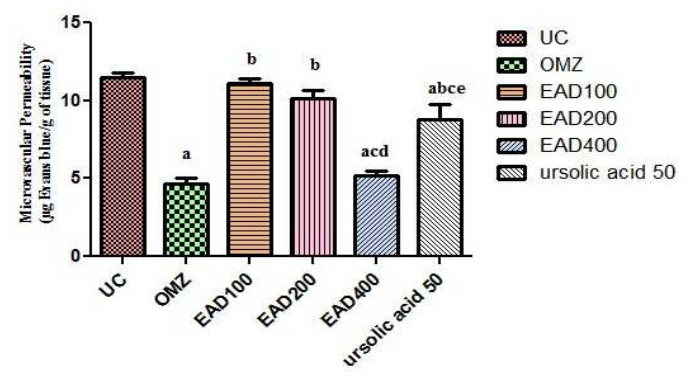

Fig. 3: Effects of EAD, ursolic acid and omeprazole on microvascular permeability in gastric mucosa induced by absolute ethanol
Statistical comparison was determined by one-way ANOVA followed by the Tukey's multiple comparison tests. (a) $\mathrm{P}<0.05$, statistically significant as compared to ulcer control. (b) $\mathrm{P}<0.05$, statistically significant as compared to omeprazole. (c) $\mathrm{P}<0.05$, statistically significant as compared to EAD 100 . (d) $P<0.05$, statistically significant as compared to EAD200. (e) $p<0.05$ statistically significant as compare to EAD400.

\section{Effect of root extract of $\boldsymbol{A}$. dichotoma on mucus content}

Graded doses of EAD, ursolic acid and omeprazole did not show any significant effect on the mucus content when compared to the ulcer control group (fig. 4).

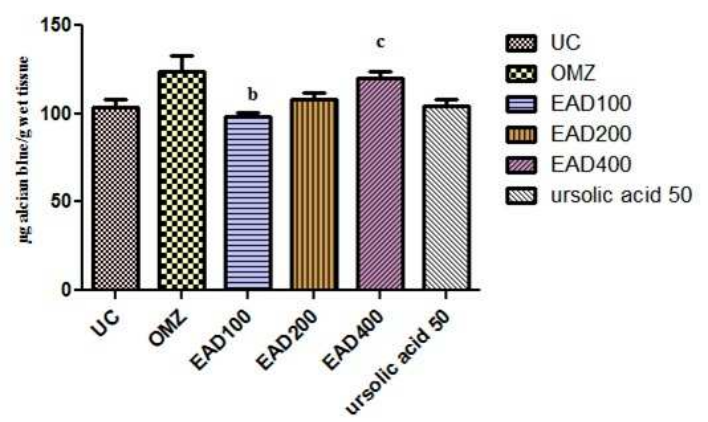

Fig. 4: Effects of mucus content by EAD, ursolic acid and omeprazole in $1 \mathrm{~h}$ absolute ethanol-induced gastric ulcer in rats All statistical comparison was determined by one-way ANOVA followed by the Tukey's multiple comparison tests, (b) $\mathrm{P}<0.05$, statistically significant as compared to omeprazole, (c) $P<0.05$, statistically significant as compared to EAD 100

Effect of EAD on antioxidant enzymes and free radical generation

Administration of absolute ethanol in the ulcerated control group increased the level of LPO while decreased the level of SOD, GSH and CAT as compared to the normal control group. EAD (200 and 400 $\mathrm{mg} / \mathrm{kg}$, p. o.), ursolic acid $(50 \mathrm{mg} / \mathrm{kg}$, p. o.) and standard drug omeprazole $(20 \mathrm{mg} / \mathrm{kg}$, p. o.) pretreatment significantly leveled the antioxidant enzyme as a result, leading to decrease in LPO level while SOD, GSH and CAT values showed significant increase (table 6).

\section{Histopathological studies}

In the microscopic observation of ethanol induced ulcer causes gastric lesions, leading to disruption of surface epithelium, erosion, necrosis and hemorrhage, thus changing the normal architecture of the stomach mucosa. Protection against these histopathological changes was observed in pretreatment with EAD graded doses $(100$, 200 and $400 \mathrm{mg} / \mathrm{kg}$, p. o.), ursolic acid $(50 \mathrm{mg} / \mathrm{kg}$, p. o. $)$ and omeprazole $(20 \mathrm{mg} / \mathrm{kg}, \mathrm{p}$. o.) offered significant protection to the mucosa and reduced size of ulcer caused by ethanol (fig. 5 and 6).

Table 6: Effect of extract and ursolic acid on the levels of LPO, SOD, CAT and glutathione (GSH) in rats with gastric ulcers induced by absolute ethanol

\begin{tabular}{|c|c|c|c|c|}
\hline \multirow[t]{2}{*}{ Groups } & \multirow[t]{2}{*}{ LPO (MDA, nmol/g tissue) } & \multicolumn{3}{|l|}{ Antioxidant enzymes } \\
\hline & & SOD (units/g tissue) & CAT (units/g tissue) & GSH ( $\mu \mathrm{g}$ GSH/g tissue) \\
\hline Normal control & $70.78 \pm 1.44$ & $37.01 \pm 0.33$ & $32.29 \pm 0.75$ & $248.84 \pm 4.83$ \\
\hline Ulcer control & $93.05 \pm 0.93^{\mathrm{a}}$ & $18.79 \pm 0.41^{\mathrm{a}}$ & $13.96 \pm 1.88^{\mathrm{a}}$ & $108.51 \pm 7.17^{\mathrm{a}}$ \\
\hline Omeprazole 20 & $44.24 \pm 1.20^{\mathrm{ab}}$ & $32.41 \pm 0.32^{\mathrm{ab}}$ & $29.19 \pm 0.70^{b}$ & $234.77 \pm 4.36^{b}$ \\
\hline EAD 100 & $75.93 \pm 1.51^{\mathrm{bc}}$ & $19.41 \pm 0.38^{\mathrm{ac}}$ & $17.33 \pm 1.72^{\mathrm{ac}}$ & $148.19 \pm 4.71^{\mathrm{abc}}$ \\
\hline EAD 200 & $63.09 \pm 1.17 \mathrm{abcd}$ & $24.19 \pm 0.56^{\mathrm{abcd}}$ & $24.71 \pm 0.44^{\mathrm{abd}}$ & $197.61 \pm 5.04^{\mathrm{abcd}}$ \\
\hline EAD 400 & $43.73 \pm 1.60^{\text {abde }}$ & $31.22 \pm 0.42^{\text {abde }}$ & $27.12 \pm 0.85^{\mathrm{abd}}$ & $234.05 \pm 2.89$ bde \\
\hline Ursolic acid 50 & $71.47 \pm 1.98^{\text {bcef }}$ & $22.16 \pm 1.38^{\mathrm{abcf}}$ & $21.41 \pm 0.93^{\mathrm{abcf}}$ & $156.73 \pm 3.17$ abcef \\
\hline
\end{tabular}

All statistical data was expressed in mean \pm SEM and determined by one-way ANOVA followed by Tukey's multiple comparison test, ap $<0.05$ statistically significant as compare to normal control, b ${ }^{\mathrm{p}}<0.05$ statistically significant as compare to ulcer control, c $\mathrm{p}<0.05$ statistically significant as compare to omeprazole, ${ }^{d} p<0.05$ statistically significant as compare to EAD100, ${ }^{\mathrm{e}} \mathrm{p}<0.05$ statistically significant as compare to EAD200, ${ }^{\mathrm{p}} \mathrm{p}<0.05$ statistically significant as compare to EAD 400 


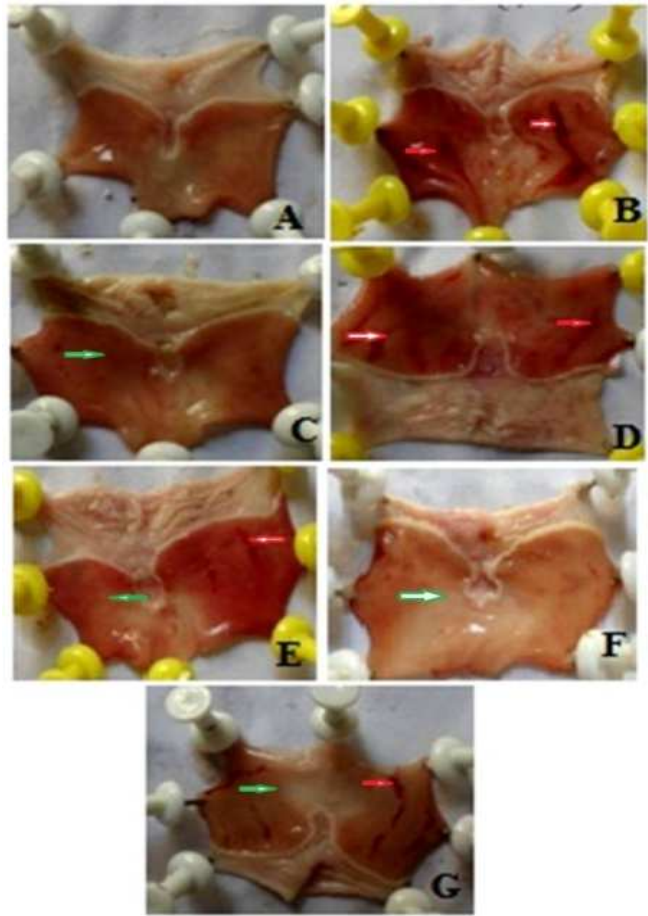

Fig. 5: Macroscopic observation of gastric mucosal lesions in Ethanol induced ulcer model

(A) Normal control (B) ulcer control (C) Omeprazole $(20 \mathrm{mg} / \mathrm{kg}$ ) pretreated group (D-F) Pretreated EAD doses at 100, 200 and 400 $\mathrm{mg} / \mathrm{kg}$ (G) Ursolic acid (50 mg/kg, p. o.). ((Indications of arrow marks: Red: Gastric pit lesions formation; Green: stomach normal architecture with less or no ulcer formation).
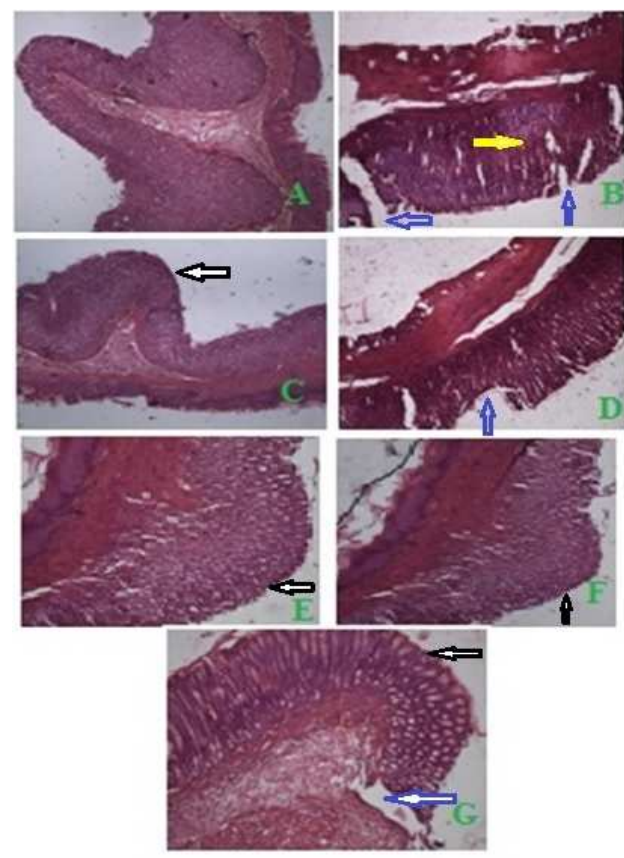

Fig. 6: Histological evaluations for the protective effect of EAD and ursolic acid, (A) Normal control (B) ulcer control (C)

Omeprazole $(20 \mathrm{mg} / \mathrm{kg})$ pretreated group (D-F) Pretreated EAD doses at 100, 200 and $400 \mathrm{mg} / \mathrm{kg}$ (G) Ursolic acid (50 mg/kg, p. o.) on ethanol-induced gastric damage in rat stomach tissues.(Indications of arrow marks: Blue: Severe surface epithelium detachment; Yellow: haemorrhage, Black: stomach normal architecture with less or no ulcer formation)

\section{DISCUSSION}

In the present study, ursolic acid from a petroleum ether fraction of EAD was isolated and reported for the first time. The oral acute and sub-acute toxicity study of EAD illustrates that EAD to be a safe drug up to $5000 \mathrm{mg} / \mathrm{kg}$, p. o. The gastroprotective effect of EAD and ursolic acid has been demonstrated, and it efficiently protected the animals against acute gastric ulcer caused by various ulcerogens. Ethanoland PL models lead to a determination of mechanism of action by the biochemical studies on various aggressive and defensive parameters. 200 and $400 \mathrm{mg} / \mathrm{kg}$, p. o., a dose of EAD and ursolic acid $(50 \mathrm{mg} / \mathrm{kg}$, p. o.) showed significant gastric ulcer protective effect on absolute ethanol and PL induced gastric ulcers in rats. PL induced ulcer model increased the accumulation of gastric acid and pepsin which is responsible for autodigestion of gastric mucosa and ruptured the gastric mucosal barrier [40]. The increased gastric acid secretion stimulates the pressure receptors in the antral gastric mucosa, which activate the vagus-vagal reflux in the hypersecretion model of PL [40]. The current data clearly demonstrated that EAD and ursolic acid-treated rats showed a significant increase in gastric $\mathrm{pH}$ as compared to ulcer control while gastric juice volume and total acid-pepsin output was notably reduced in the $4 \mathrm{~h}$ PL-rats. However, defensive factors (total mucin activity) were not altered significantly. Effect of EAD (200 and 400 $\mathrm{mg} / \mathrm{kg}$, p. o.) and ursolic acid (50 mg/kg, p. o.) on cell shedding in the $4 \mathrm{~h}$ PL rats depicted decrease in the gastric juice DNA content which was significant, but the level of mucosal DNA content which signifying the lack of effects on the mucosal cell proliferation were unaffected. Thus, the possible mode of action of EAD and ursolic acid might be accredited mainly to the antisecretory effect (offensive factor) and not due to the mucin activity (defensive factor). Antisecretory effect of EAD was further supported by the evaluation of the $\mathrm{H}^{+} \mathrm{K}^{+}-\mathrm{ATPase}$ activity. $\mathrm{H}^{+} \mathrm{K}^{+}$-ATPase residing in parietal cells is a membrane-bound enzyme which act as a vehicle of $\mathrm{H}^{+}$, by utilizing energy released by hydrolysis of ATP which on reaction with luminal Clgenerates $\mathrm{HCl}$ in the stomach. Thus $\mathrm{H}^{+} \mathrm{K}^{+}$-ATPase plays a pivotal role in the generation of gastric acid [25]. Hence, the antisecretory effect may be the result of $\mathrm{H}^{+} \mathrm{K}^{+}$-ATPase inhibition. The result showed that EAD (200 and $400 \mathrm{mg} / \mathrm{kg}$, p. o.) significantly inhibited the $\mathrm{H}^{+} \mathrm{K}^{+}$-ATPase enzyme. Therefore, decrease acid secretion as a result of proton pump inhibition might impart the gastro protective activity to EAD while ursolic acid does not act on proton pump inhibition. Although ursolic acid may play an important role in ulcer treatment, but it shows the lesser effect as compare to EAD (400 $\mathrm{mg} / \mathrm{kg}, \mathrm{p}$. o.). Ethanol depletes the defensive factors of the mucosa, particularly the mucosal barrier, leading to the destruction of gastric wall mucus due to its potent necrotizing effect [42]. The result of ethanol induced ulcer showed that pretreatment with EAD (400 $\mathrm{mg} / \mathrm{kg}, \mathrm{p} . \mathrm{o}$.) protected the mucosa from the erosive effect of ethanol with percentage protection of $77.6 \%$ on ulcer which was as high as comparable to the standard drug omeprazole (82.74\%). Pretreatment with EAD at all dose levels showed a significant decrease in the LPO level while the increase in SOD, CAT and GSH level. Reactive oxygen species is one of the endogenous aggressive factors in ulcer and can be excluded by augmenting articulation of antioxidant enzymes such as SOD, CAT and GSH or by eliminating the free radicals like LPO [43, 44]. Generation of free radicals including peroxynitrite and hydroxyl radicals are inhibited by an elevated level of superoxide dismutase (SOD) as a result of dismutation of superoxide radicals. Moreover, antioxidant like glutathione (GSH) in turn eradicates deleterious free radicals by scavenging or by catalyzing the reduction of $\mathrm{H}_{2} \mathrm{O}_{2}$ and lipid peroxides [45]. The in vitro antioxidant activity of EAD has been reported in the previous paper which further acts as supporting evidence to the study where EAD was showed the protective effect to absolute ethanol-induced damage to gastric tissue by antioxidative effects [46].

Histopathological studies (fig. 6) of ethanol-induced positive control rats (B) suggested the extensive rupture of surface epithelium, development of gastric pit lesions, haemorrhage and loss of normal glandular architecture of the stomach. Rats pretreated with standard drug omeprazole (C) showed a restitution of normal control (A) stomach in which the gastric mucosal cells, gastric pits and gastric glands were together, normal and no profusion and haemorrhage observed. Rats pretreated with EAD (200-400 mg/kg; p. o.) and 
ursolic acid (50 mg/kg, p. o.) were close to normal architecture of the entire gastric mucosa as compared to normal rats.

Ursolic acid has been reported to possess hepatoprotective, antiinflammatory, anti-tumor, antihyperlipidemic and anti-ulcer activity [47]. It is a triterpenoid compound having a free hydroxyl group at position $\mathrm{C}-3$ of the triterpenoid structure which mainly attributes to its antiulcer activity [48]. According to Lee et al. (2009), ursolic acid also diminished $\mathrm{HCl}$-induced gastric lesions in mice due to antacid effects or cytoprotective properties in gastric mucus [49]. Quantification study revealed the presence of significant amount of polyphenolics and saponin in EAD. Antiulcer efficacy of flavonoids is primarily by the ability to defend the gastric mucosa against ulcer-causing agents by a diverse mechanism such as free-radical scavenging and antioxidant properties, marked increase in mucus production and antisecretory activity. Phenolics exhibit antioxidant properties by the virtue to scavenge free radicals by breaking radical chain reactions, attenuating peroxides level and triggering antioxidant defence enzyme system contributing to the antiulcer effect. The astringent action of tannin stimulates protein precipitating and vasoconstriction resulting information of impenetrable protective barrier preventing gastric ulcer by reducing the number of ulcer score. Moreover, saponin activates mucous membrane protective elements [50,51]. Therefore polyphenolics and saponin along with ursolic acid present in the EAD may act in a synergistic manner to produce antiulcer activity.

\section{CONCLUSION}

In conclusion, this study demonstrates that EAD exhibit antiulcer activity in a dose-dependent manner, the mainly antisecretory effect due to $\mathrm{H}^{+} \mathrm{K}^{+}$-ATPase inhibitory activity and also by acting as an effective antioxidant. The antiulcer effect of isolated ursolic acid (50 $\mathrm{mg} / \mathrm{kg}$, p. o.) and EAD (200 mg/kg, p. o.) were very similar and comparable while EAD (400 mg/kg, p. o.) was found to be most potent. Thus, the present finding scientifically confirms the traditional use of $A$. dichotoma in the treatment of gastric ulcer.

\section{ACKNOWLEDGEMENT}

Deepali Pandey is thankful to the Indian Institute of Technology (Banaras Hindu University), Varanasi for the financial support. Author also wished to acknowledge Dr. K. Madhava Chetty, Taxonomist, S. V. University, Tirupati for the collection and authentication of the plant material.

\section{AUTHOR CONTRIBUTION}

Deepali Pandey was involved in all the experimental work, analysed the data and drafted the paper under the supervision of Dr. (Mrs.) S. Hemalatha who planned and critically reviewed the manuscript. Apurva Joshi was involved in conduction and analysis of HPTLC.

\section{CONFLICT OF INTERESTS}

No conflict of interest has been reported by all the authors.

\section{REFERENCES}

1. Srikanta BM, Siddaraju MN, Dharmesh SM. A novel phenolbound pectic polysaccharide from Decalepis hamiltonii with multi-step ulcer preventive activity. World J Gastroenterol 2007;13:5196-207.

2. Groenen MJ, Kuipers EJ, Hansen BE, Ouwendijk RJ. The incidence of duodenal ulcers and gastric ulcers in a Western population: Back to where it started. Can J Gastroenterol 2009;23:604-8.

3. Miller TA. Mechanisms of stress-related mucosal damage. Am J Med 1987;83:8-14.

4. Kangwan N, Park JM, Kim EH, Hahm KB. The quality of healing of gastric ulcers: Natural products beyond acid suppression. World J Gastrointest Pathophysiol 2014;5:40-7.

5. Khan MSA, Jais AMM, Afreen A. Prostaglandin analogue and anti-oxidant activity mediated gastroprotective action of Tabernaemontana divaricata (L.) $\mathrm{R}$. Br. Flower methanolic extract against chemically induced gastric ulcers in rats. Biomed Res Int 2013;2013:1-18.

6. Rao ChV, Ojha SK, Radhakrishnan K, Govindarajan R, Rastogi S, Mehrotra S, et al. Antiulcer activity of Utleria salicifolia rhizome extract. J Ethnopharmacol 2004;91:243-9.
7. Hewageegani HGSP, Ariyawansal HAS, Ratnasooriya WD. Gastroprotective activity of the paste of Evolvulus alsinoides L. (vishnukranti kalka) in rats. Vidyodaya J Sci 2006;13:23-31.

8. Alkofahi A, Atta AH. Pharmacological screening of the antiulcerogenic effects of some Jordanian medicinal plants in rats. J Ethnopharmacol 1999;67:341-5.

9. Schmeda-Hirschmann G, Yesilada E. Traditional medicine and gastroprotective crude drugs. J Ethnopharmacol 2005;100:61-6.

10. Wiart C. Ethnopharmacology of medicinal plants: asia and the pacific. Human Press Inc; 2006. p. 16.

11. Don G. Aganosma. In: A general history of the dichlamydeous plants. Vol. 4. London: CJG and F Rivington; 1837. p. 77.

12. Middleton David J. A revision of Aganosma (Blume) G. Don (Apocynaceae). Kew Bull 1996;51:455-82.

13. Kirtikar KR, Basu BD. Indian medicinal plants. dehradun, India: M/s Bishen Singh Mahendra Pal Singh; 1975. p. 1587.

14. Vaidya BD, Kashyap L. Materia Medica of Ayurveda. New Delhi, India: Concept Publishing Company; 2000.

15. Trease GE, Evans WC. Pharmacognosy. Fifteenth Ed. W. B. Saunders Company Ltd., London; 2002.

16. Makkar HPS. Quantification of tannins in tree foliage: A laboratory manual for the FAO/IAEA co-ordinated research project on 'Use of nuclear and related techniques to develop simple tannin assays for predicting and improving the safety and efficiency of feeding ruminants of tanniniferous tree foliage'. Joint FAO/IAEA of Nuclear; Techniques in Food and Agriculture, Animal Production and Health Sub-programme. FAO/IAEA working document; Vienna; 2000. p. 3-5.

17. Kumaran A, Karunakaran J. In vitro antioxidant activities of methanol extracts of five Phyllanthus species from India. Food Sci Tech 2006;40:344-52.

18. Baccou JC, Lambert F, Sauvaire Y. Spectrophotometric method for the determination of total steroidal sapogenin. Analyst 1977;102:458-65.

19. Gupta M, Bisht D, Khatoon S, Srivastava S, Rawat AKS. Determination of ursolic acid a biomarker in different Swertia species through high-performance thin layer chromatography. Chinese Med 2011;2:121-4.

20. Organization for Economic Co-operation and Development. Guidelines for testing of chemicals. Guidance no. 425, Acute oral toxicity: up and down procedure (UDP). Available from: http://iccvam.niehs.nih.gov/Supp/Docs/Fed Docs/OECD/OECD tg425.pdf. [Last accessed on 03 Oct 2008]

21. Singh GK, Kumar V. Acute and subchronic toxicity study of a standardized extract of Fumaria indica in rodents. J Ethnopharmacol 2011;134:992-5.

22. Shay M, Komarov SA, Fels SS, Meranze D, Gruenstein M, Siplet H. A simple method for the uniform production of gastric ulceration in the rat. Gastroenterol 1945;5:43-61.

23. Shanti A, Radha R, Jaysree A. Antiulcer activity of newly formulated herbal capsule. Asian J Pharm Clin Res 2011;4:86-9.

24. Sanyal AK, Mitra PK, Goel RK. A modified method to estimate dissolved mucosubstances in gastric juice. Indian J Exp Biol 1983;21:78-80.

25. Laloo D, Prasad SK, Sairam K, Hemalatha S. Gastroprotective activity of ethanol root extract of Potentilla fulgens Wall ex Hook. J Ethnopharmacol 2013;146:505-14.

26. Lowry $\mathrm{OH}$, Rosenborough NJ, Farr AL, Randal RJ. Protein measurement with folin phenol reagent. J Biol Chem 1951; 193:265-75.

27. Mukhopadhyay K, Bhattacharya D, Chakrabarti A, Goel RK, Sanyal AK. Effect of banana powder (Musa sapientum var. paradisiaca) on gastric mucosal shedding. J Ethnopharmacol 1987;21:11-9.

28. Reyes-Chilpa R, Baggio CH, Alavez-Solano D, Estrada-Muniz E, Kauffman FC, Sanchez RI, et al. Inhibition of $\mathrm{H}^{+} \mathrm{K}^{+}$-ATPase gastric activity by flavonoids, coumarins and xanthones isolated from Mexican medicinal plants. J Ethnopharmacol 2006;105:167-72.

29. Griswold B, Humoller FL, McIntyre AR. Inorganic phosphate and phosphate ester in tissue extracts. Anal Chem 1951;23:192-4.

30. Sairam K, Priyambada S, Aryya NC, Goel RK. Gastroduodenal ulcer protective activity of Asparagus racemosus: an experimental, biochemical and histological study. J Ethnopharmacol 2003;86:1-10. 
31. Morsy MA, Heeba GH, Abdelwahab SA, Rofaeil RR. Protective effects of nebivolol against cold restraint stress-induced gastric ulcer in rats: role of NO, HO-1, and COX-1, 2. Nitric Oxide 2012;27:117-22.

32. Rajasekaran S. Antiulcer activity of a different extract of Kigelia pinnata in experimental animals. Asian J Pharm Clin Res 2014;7:80-3.

33. Katayama S, Shionoya $\mathrm{H}$, Ohtake S. A new method for extraction of extravasated dye in the skin and the influence of fasting stress on passive cutaneous anaphylaxis in guinea pigs and rats. Microbiol Immunol 1978;22:89-101.

34. Corne SJ, Morrissey SM, Woods RJ. Proceedings: a method for the quantitative estimation of gastric barrier mucus. J Physiol 1974;242:116-7.

35. Das D, Banerjee RK. Effect of stress on the antioxidant enzymes and gastric ulceration. Mol Cell Biochem 1993;125:115-25.

36. Kakkar P, Das B, Viswanathan PN. A modified spectrophotometric assay of superoxide dismutase. Indian J Biochem Biophys 1984;21:130-2.

37. Beers RF, Sizer IW. A spectrophotometric method for measuring the breakdown of hydrogen peroxide by catalase. J Biol Chem 1952;195:133-40.

38. Sedlak J, Lindsay RH. Estimation of total protein bound and non-protein sulfhydril groups in tissues with Ellman's reagent. Anal Biochem 1968;25:192-205.

39. Ohkawa H, Ohishi N, Yagi K. Assay for lipid peroxides in animal tissues by thiobarbituric acid reaction. Anal Biochem 1979;95:351-8.

40. Goel RK, Bhattacharya SK. Gastroduodenal mucosal defence and mucosal protective agents. Indian J Exp Biol 1991;29:701-14.

41. Baggio CH, Frietas CS, Otofuji GDM, Cipriani TR, Souza LM, Sassaki GL, et al. a Flavonoid-rich fraction of Maytenus ilicifolia Mart. ex reiss protects the gastric mucosa of rodents through inhibition of both $\mathrm{H}^{+} \mathrm{K}^{+}$ATPase activity and formation of nitric oxide. J Ethnopharmacol 2007;113:433-40.
42. Wallace JL. Mechanisms of protection and healing: current knowledge and future research. Am J Med 2001;110:19-23.

43. Ikasari ED, Utomo AB, Setyopuspito A, Adhityaasmara D, Setyowati H. Evaluation of antiulcer activity of mucoadhesive micro granules containing ranitidine hydrochloride in experimental rats. Int J Curr Pharm Res 2017;9:45-9.

44. Joshi A, Joshi VK, Pandey D, Hemalatha S. Systematic investigation of ethanolic extract from Leea macrophylla: Implications in wound healing. J Ethnopharmacol 2016;191:95106.

45. Joshi A, Sengar N, Prasad SK, Goel RK, Singh A, Hemalatha S. Wound healing potential of the root extract of Albizzia lebbeck. Planta Med 2013;79:737-43.

46. Pandey D, Joshi A, Hemalatha S. Quality control standardization and in vitro antioxidant activity of Aganosma dichotoma $\mathrm{K}$ Schum root. Pharmacogn J 2015; 7:74-82.

47. Liu J. Pharmacology of oleanolic acid and ursolic acid. J Ethnopharmacol 1995;49:57-68.

48. Navarrete A, Trejo-Miranda JL, Reyes-Trejo L. Principles of root bark of Hippocratea excels (Hippocrataceae) with gastroprotective activity. J Ethnopharmacol 2002;79:383-8.

49. Lee JH, Lee DU, Jeong CS. Gardenia jasminoides Ellis ethanol extract and its constituents reduce the risks of gastritis and reverse gastric lesions in rats. Food Chem Toxicol 2009;47:1127-31.

50. Sumbul S, Ahmad MA, Asif M, Akhtar M. Role of phenolic compounds in peptic ulcer: an overview. J Pharm Bioall Sci 2011;3:361-7.

51. Borrelli F, Izzo AA. The plant kingdom as a source of anti-ulcer remedies. Phytother Res 2000;14:581-91.

\section{How to cite this article}

- Deepali Pandey, Apurva Joshi, Siva Hemalatha. Anti-ulcer study of standardized ethanol root extract of Aganosma dichotoma and isolated Ursolic acid. Int J Pharm Pharm Sci 2017;9(4):172-180. 